\title{
JOURNAL.RU
}

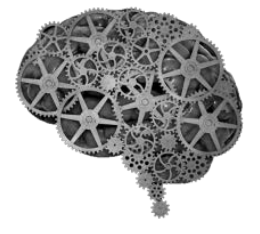

COMPANY GROUP "INTELLEKT"

\author{
Упоров И.В. \\ Краснодарский университет МВД России \\ Краснодар, Россия
}

doi: 10.18411/lj2016-6-4-11

\section{Система исполнительных органов государственного и муниципального управления в сфере дорожного хозяйства россии}

Аннотация: В статье рассматриваются особенности правового статуса органов государственного и муниципального управления в области дорожного хозяйства в нашей стране, при этом внимание акцентируется на их полномочиях. Отмечается, что дорожное хозяйство еще не имеет своей четкой ведомственной принадлежности, в связи чем статусные полномочия исследуемых органов по ряду вопросов находят противоречивое правовое регулирование. Обосновываются предложения по его совершенствованию, в частности, предлагается воссоздать Министерство автомобильного транспорта по опыту прошлых времен.

Ключевые слова: дорожное хозяйство, органы управления, правовой статус, полномочия, исполнительная власть, Минтранс, Росавтодор.

Управленческое воздействие административно-правовыми методами в сфере дорожного хозяйства осуществляют исполнительные органы государственного и муниципального управления всех трех публичнотерриториальных уровней - федерального, регионального и муниципального. Рассмотрим особенности их структурирования и правового статуса, акцентируя внимания на федеральных органах - с учетом того, что соответствующие органы все уровней применяют по сути одни и те же методы административно- 
правового регулирования, и различие заключается в основном в масштабе объектов управленческого воздействия и юридической силе принимаемых решений.

На федеральном уровне структура административного управления дорожным хозяйством включает в себя следующие органы исполнительной власти и управления: а) Правительство Российской Федерации; б) Министерство транспорта Российской Федерации; в) Федеральная служба по надзору и контролю в сфере транспорта (Ространснадзор); г) Федеральное дорожное агентство (Росавтодор). По мнению В.В. Кретова, в эту структуру управления дорожным хозяйством включаются также «федеральные дорожные государственные и казенные учреждения, подведомственные Росавтодору и осуществляющие функции оперативного управления федеральными автодорогами и государственных заказчиков работ по их строительству, реконструкции и эксплуатации, а также ФГУП , осуществляющие конкретные виды деятельности» [1, с. 64].

Однако такой подход представляется неоднозначным и требует уточнения. И здесь, как мы полагаем, следует определиться с тем, какое «управление» имеется в виду. В настоящей статье мы рассматриваем управленческое воздействие в сфере дорожного хозяйства исключительно методами административно-правового регулирования, а полномочиями осуществлять таковые могут только соответствующие органы (должностные лица) исполнительной власти. В своей работе указанный автор (В.В. Кретов) ведет речь об «управлении» без уточнения характера такового, из чего можно сделать вывод, что он имеет в виду всех субъектов управления, то есть речь идет об общем управлении без акцента на административное управление. При общем управлении действительно структура управления дорожным хозяйством может включать в себя не только органы публичной власти, но и иные организации, и прежде всего создаваемые органами власти для решения отдельных вопросов функционирования дорожного хозяйства (включая прежде всего гокомпанию 
«Российские автомобильные дороги», а также ФКУ, МУ, ГУП, МУП и др.), а также организации, созданные в инициативном порядке (и такие уже имеются: Российская ассоциация территориальных органов управления автомобильными дорогами - РАДОР, Российская ассоциация подрядных организаций в дорожном хозяйстве - АСПОР, Российская организация дорожных проектных организаций - РОДОС).

Еще раз подчеркнем - указанные организации (все они создаются не иначе как в соответствии с ГК РФ или на основании специальных законов) могут быть (и есть) звеньями управления в сфере дорожного хозяйства Российской Федерации, но они по степени императивности приминаемых решений, а значит, и по степени влияния на состояние дел в этой сфере, являются производными, то есть полномочия по административному управлению им делегируются органами публичной власти в том объеме и такого характера, которые органы публичной власти сочтут целесообразным.

Правительство Российской Федерации в данной структуре является органом федеральной власти общей (универсальной) компетенции. В соответствии с ФКЗ «О Правительстве Российской Федерации» [2] решения этот коллегиальный орган принимает на своих заседаниях, которые считаются правомочным, если на нем присутствуют не менее половины членов Правительства. Решения принимаются, как правило, общим согласием, достигаемым на предварительных стадиях подготовки и согласования проектов актов. На основании предложения члена Правительства по решению председательствующего может быть проведено голосование. В этом случае решение принимается большинством голосов присутствующих на заседании членов Правительства. При равенстве голосов решающим является голос председательствующего на заседании [3].

Процедурные аспекты (подготовка проектов актов, согласование проектов актов, внутренняя экспертиза проектов и т.д.) регулируются Регламентом Правительства РФ [4] и разработанной на его основе Инструкцией по 
делопроизводству в Аппарате Правительства, утвержденной заместителем Председателя Правительства - Руководителем Аппарата Правительства РФ. Следует заметить, что в ФКЗ «О Правительстве Российской Федерации» имеется ряд статей (ст. 14-21), где указываются полномочия Правительства РФ в определенных сферах общественных отношений. Ни вопросы транспорта, ни тем более вопросы дорожного хозяйства в них не значатся, что, на наш взгляд, неправильно, учитывая значимость транспорта для социально-экономического развития общества. В этой связи представляется целесообразным в данном законе добавить статью с указанием полномочий в транспортной сфере. Пока же Правительство РФ в сфере дорожного хозяйства исходит из общих полномочий в сфере экономики (ст. 14), при этом вопросы на заседание Правительства готовят Министерство транспорта РФ, Федеральная служба по надзору и контролю в сфере транспорта, Росавтодор, а также структурные подразделения Аппарата Правительства РФ (Департамент транспорта, Управление автомобильных дорог)

Министерство транспорта РФ в контексте рассматриваемой темы является уже органом государственного управления специальной компетенции. Положение о Министерстве транспорта утверждено Постановлением Правительства РФ в середине 2004 г. [5] Данный орган согласно п. 1 Положения является федеральным органом исполнительной власти в области транспорта, осуществляющим функции по выработке государственной политики и нормативно-правовому регулированию в этой сфере. Обращает на себя внимание то обстоятельство, что самый крупный раздел Положения (Второй раздел - «Полномочия») подвергался многочисленным изменениям. Достаточно сказать, что не менее $80 \%$ действующих в настоящее врем полномочий Минтранса были либо изменены либо введены дополнительно; значительная часть была исключена. Мы полагаем, что такая чехарда с этим, казалось бы, аппаратным документом, свидетельствует о наличии серьезных проблем в сфере 
административного управления сферой транспорта в целом и автомобильного в частности.

Так, только в период 2011-2015 гг. в Положение были введены следующие дополнительные полномочия Министерства транспорта, касающиеся автомобильного транспорта и дорожного хозяйства, а именно данное ведомство получило полномочия самостоятельно принимать следующие нормативноправовые акты: нормативные правовые акты по перевозке опасных грузов в международном, междугороднем, пригородном и городском сообщении, издаваемые в соответствии с Европейским соглашением о международной дорожной перевозке опасных грузов; акты, определяющие перечень мероприятий по подготовке работников юридических лиц и индивидуальных предпринимателей, осуществляющих перевозки автомобильным транспортом и городским наземным электрическим транспортом, к безопасной работе и транспортных средств к безопасной эксплуатации; критерии и порядок определения вида выполняемой международной автомобильной перевозки груза и др.

Мы полагаем, что Минтранс не в состоянии эффективно управлять одновременно всеми видами транспорта (дорожного, водного и т.д.) ввиду их существенных различий, и выделение все новых и новых полномочий по каждому виду транспорта представляется не лучшим направлением в развитии системы управления транспортом в России.

Федеральная служба по надзору и контролю в сфере транспорта (Ространснадзор) функционирует на основе Положения об этой службе, утвержденного Постановлением Правительства РФ [6] и осуществляет свою деятельность непосредственно и через свои территориальные органы. Внутриорганизационные и внутриведомственные взаимоотношения складываются между Руководителем Ространснадзора, его четырьмя заместителями, курирующими работу 10 управлений и филиалов Ространснадзора. Так, в Управление государственного автомобильного и 
дорожного надзора входят пять отделов, один из которых осуществляет непосредственную работу с объектами и предприятиями дорожного хозяйства. Следует отметить, что с момента своего учреждения (2004 г.) Ространснадзор не нашел еще своего определенного места в системе контроля за функционированием органов дорожного хозяйства [1]. Об этом свидетельствует, в частности, то обстоятельство, что в 2010 г. пришлось издавать отдельный правовой акт о полномочиях должностных лиц Ространснадзора, осуществляющих контрольные (надзорные) функции [7]. Этим актом вводится институт государственных транспортных инспекторов - лиц, которые осуществляют надзорные (контрольные) функции. В рассматриваемой нами сфере дорожного хозяйства предусмотрен ограниченный круг вопросов, которые должны надзирать государственные инспекторы - в частности, на автомобильном транспорте и в дорожном хозяйстве они осуществляют надзор на соблюдением: правил перевозок пассажиров и багажа автомобильным транспортом; правил осуществления международных перевозок по территории Российской Федерации грузовыми транспортными средствами или автобусами; требований к сохранности автомобильных дорог федерального значения. Кроме того, применительно ко всем видам транспорта госинспекторы осуществляют контроль за обеспечением транспортной безопасности; готовностью аварийноспасательных служб и формирований субъектов транспортного комплекса; реализацией мер по снижению вредного воздействия транспорта на окружающую среду. Следует заметить, что область госнадзора (контроля) в сфере автотранспорта и дорожного хозяйства явно нуждается в упорядочивании ввиду нечеткости предмета надзора (контроля) и надзирающих (контрольных) структур.

Важнейшим звеном в осуществлении управленческого воздействия на дорожное хозяйство методами административно-правового регулирования является Федеральное дорожное агентство (Росавтодор), которое действует на основании соответствующего Положения, утвержденного Правительством РФ в 
2004 г. [8] Этим актом определен довольно обширный перечень полномочий Росавтодора, где большая часть относится к методу разрешительного регулирования. В частности, Росавтодор в части осуществления управленческого воздействия на дорожное хозяйство методами административно-правового управления: принимает в эксплуатацию законченные строительством, реконструкцией и ремонтом участки автомобильных дорог общего пользования федерального значения; определяет маршруты движения по автомобильным дорогам общего пользования федерального значения транспортных средств с крупногабаритными и тяжеловесными грузами, в том числе осуществляющих международные перевозки в соответствии со специальными разрешениями; предоставляет земельные участки, которые находятся в федеральной собственности или государственная собственность на которые не разграничена, для размещения автомобильных дорог федерального значения и др.

Как показывается анализ Положения о Роставтодре, данный перечень также (как в случае с полномочиями Министерства транспорта) в значительной мере изменен, в том числе введен ряд новых полномочий. Это обстоятельство подтверждает наш тезис о том, что административно-правовое регулирование в сфере дорожного хозяйства нуждается в серьезном совершенствовании. Мы предполагаем, что, очевидно, назрела необходимость полного обновления соответствующей законодательной базы.

Что касается организационно-правовой основой управления дорожным хозяйством в субъектах РФ и муниципальных образованиях, то она формируется по разному в зависимости от конкретного состояния дорожного хозяйства, находящего в зоне соответствующего административно-правового регулирования. Обычно в субъектах не выделяются специальные дорожные управленческие структуры, и дорожное хозяйство управляется региональными органами управления, которые ответственны в целом за всю транспортную сферу, либо органами, ответственными за строительство и ЖКХ. Так, в 
Астраханской области функционирует Министерство строительства и дорожного хозяйства, а в Краснодарском крае предусмотрено Министерство транспорта и дорожного хозяйства.

Как видно, дорожное хозяйство как имущественный комплекс социальноэкономического значения еще не получил определенной ведомственной принадлежности, и данное обстоятельство усложняет административноправовое регулирование данной сферы общественных отношений, в том числе объясняет те противоречия в законодательных актах, о которых говорилось выше. В муниципальных образованиях тем более нет специальных подразделений местных администраций в силу относительно небольшого масштаба местного дорожного хозяйства. В целом, как отмечает В.В. Кретов, единой структуры органов управления дорожным хозяйством как на региональном, так и на муниципальном уровне, нет. Приводится пример негативного последствия этого и других недостатков организационной структуры управления дорожным хозяйством - так, многие обсуждаемые на коллегиях Министерства транспорта вопросы во многих случаях остаются нерешенными [1].

C учетом изложенных выше рассуждений и имея в виду обширные пространства России, а также существенные различия в организации и функционирования разных видов транспорта (воздушный, железнодорожный, автомобильный, водный), представляется целесообразным выделить самостоятельное Министерства автомобильного транспорта - по опыту советского периода, когда функционировали самостоятельные транспортные ведомства (так, ранее существовали Министерство автомобильного транспорта и шоссейных дорог СССР, Министерство дорожного и транспортного хозяйства РСФСР). Соответственно будет уменьшено количество федеральных органов управления дорожным хозяйством и повысится эффективность их управленческого воздействия. 


\section{Литература:}

1. Кретов В.В. Административно-правовое регулирование дорожного хозяйства Российской Федерации: состояние, проблемы, перспективы развития. Дис. ...канд. юрид. наук. Тюмень, 2015. С. 64.

2. Федеральный конституционный закон от 17.12.1997 N 2-ФКЗ (ред. от 14.12.2015) "О Правительстве Российской Федерации" // Справочноправовая система «Консультант +» (дата обращения - 30.01. 2016 г.).

3. Смушкин А.Б. Комментарий к Федеральному конституционному закону от 17 декабря 1997 г. N 2-ФКЗ "О Правительстве Российской Федерации" (постатейный) // СПС КонсультантПлюс. 2014.

4. Постановление Правительства РФ от 01.06.2004 N 260 (ред. от 05.02.2016) "О Регламенте Правительства Российской Федерации и Положении об Аппарате Правительства Российской Федерации" // Справочно-правовая система «Консультант +» (дата обращения - 30.01. 2016 г.).

5. Постановление Правительства РФ от 30.07 .2004 N 395 (ред. от 25.12.2015) "Об утверждении Положения о Министерстве транспорта Российской Федерации" // Справочно-правовая система «Консультант +» (дата обращения - 30.01. 2016 г.).

6. Постановление Правительства РФ от 30.07 .2004 N 398 (ред. от 25.12.2015) "Об утверждении Положения о Федеральной службе по надзору в сфере транспорта" // Справочно-правовая система «Консультант +» (дата обращения - 30.01. 2016 г.).

7. Постановление Правительства РФ от 09.06.2010 N 409 (ред. от 26.05.2011) "Об осуществлении должностными лицами Федеральной службы по надзору в сфере транспорта контрольных (надзорных) функций" (вместе с "Положением о полномочиях должностных лиц Федеральной службы по надзору в сфере транспорта, осуществляющих контрольные (надзорные) 
функции") // Справочно-правовая система «Консультант +» (дата обращения - 30.01. 2016г.).

8. Постановление Правительства РФ от 23.07.2004 N 374 (ред. от 25.12.2015) "Об утверждении Положения о Федеральном дорожном агентстве" // Справочно-правовая система «Консультант +» (дата обращения - 30.01. 2016г.). 